\title{
Naar een uitvoering van het NSV-advies
}

\author{
Leonie van Drooge
}

Met het advies Naar een evenwichtige kwaliteitsbeoordeling van sociologisch onderzoek levert de Nederlandse Sociologische Vereniging een waardevolle bijdrage aan het debat over beoordeling van academisch onderzoek. Er is in Nederland een traditie van adviezen en rapporten over kwaliteitsbeoordeling. Kort gezegd betogen alle rapporten hetzelfde: dat het bij kwaliteit van onderzoek gaat om wetenschappelijke en maatschappelijke aspecten, en dat een zinvolle manier van beoordelen aansluit bij kenmerkende eigenschappen van het te beoordelen onderzoek.

De NSV zet een belangrijke stap door als discipline gezamenlijk een visie te ontwikkelen. Eerdere adviezen waarnaar de auteurs verwijzen zijn ofwel generiek, geldend voor wetenschappelijk onderzoek in het algemeen (ERiC 2010; Van Drooge et al. 2011), ofwel gericht op het grote geheel van de sociale wetenschappen (KNAW 2013) of geesteswetenschappen (KNAW 2011; KNAW 2012). Hoe specifieker de eenheid, des te nauwkeuriger de omschrijving van eisen aan kwaliteit. Tot zover: hulde!

Het advies kan echter op enkele punten scherper. Die aanscherping betreft punten die bij de uitvoering van belang zijn; ze betreffen niet de uitgangspunten van kwaliteitsbeoordeling of specifieke voorstellen voor toepassing. Het gaat om het maken van keuzes in de bijdragen die sociologie kan en wil maken en om het nemen van verantwoordelijkheid om die bijdrage te kunnen realiseren. Doel van deze reactie is om daartoe aan te zetten.

Een van de zorgen die de NSV uitspreekt in het advies is de nadruk op internationale peer-reviewed publicaties. De belangrijkste nadelen die de NSV hier signaleert, zijn samen te vatten als academic drift (Harwood 2010). Ik bedoel hiermee het proces waarbij wetenschappelijke kennis die mede gericht is op een bepaalde praktijk, onderdeel wordt van een body of scientific knowledge en de banden met die praktijk verliest. De NSV stelt dat de sociologie is losgezongen van de Nederlandse maatschappij. Er zijn nog maar weinig sociologen die zowel in de internationale sociologie mee kunnen komen als een publieke functie kunnen vervullen.

De NSV stelt dat academic drift is veroorzaakt door het publicatiecriterium. Maar er lijkt meer aan de hand. De NSV constateert immers ook dat er een weinig ontwikkelde toepassingspraktijk is. Daaraan zitten volgens de NSV twee nadelen: voor de empirie, en voor de toepassing van de resultaten. Dat betekent dus ook dat vragen aan de orde zijn als: Wie of wat dient de sociologie in Nederland? Voor welke praktijken is de sociologie relevant? De NSV benoemt enkele schakels tussen wetenschap en maatschappij, maar een precies antwoord blijft uit. Het gaat erom toch een antwoord te formuleren.

De vraag wie of wat de Nederlandse sociologie dient is, in het kader van een landelijk advies van een nationale vereniging, niet anders te beantwoorden dan in zeer algemene termen. Het antwoord is echter van belang als het gaat om het 
bepalen van specifieke beoordelingscriteria die maatschappelijke bijdragen van sociologie in Nederland kunnen ondersteunen. Het is immers pas zinvol te bepalen welke criteria te hanteren, als duidelijk is wat het doel is - en daarmee wat goed is. Dit gebrek aan focus is een van mijn twee bezwaren tegen het advies.

Volgens de NSV moeten sociologen de Nederlandse samenleving dienen. Dat is een duidelijke keuze, geldend voor de sociologie in haar geheel. De keuze om de vraag te beantwoorden op het niveau van een universitaire afdeling (en niet op het niveau van de individuele onderzoeker of het hele vakgebied) is verstandig. Want een afdeling kan verschil maken, kan verschillende publieken bedienen en een diversiteit aan rollen vervullen. En kan keuzes maken, toepassingspraktijken benoemen die ze wil beïnvloeden en vormen van kennisbeheer formuleren die ze wil gebruiken.

De NSV plaatst een kanttekening bij het KNAW-advies (KNAW 2013). De suggestie dat maatschappelijke relevantie gebaseerd moet zijn op eigen peer-reviewed wetenschappelijk onderzoek, zou onnodig beperkend zijn. Het zou de publieke rol van de sociologie beperken. Het punt dat de NSV maakt, is dat een deel van de communicatie en samenwerking met maatschappelijke partijen berust op het gezag van het sociaalwetenschappelijke kennisbestand in het algemeen.

Hier laat zowel de KNAW als de NSV steken vallen. Maatschappelijke relevantie (of valorisatie of welke term dan ook) gaat niet alleen over het eigen peer-reviewed onderzoek. Vaak gaat het om kennis en inzichten die onderzoekers in de loop van de tijd hebben ontwikkeld. Om expertise die waardevol is en waar derden gebruik van (kunnen) maken. Denk aan het duiden van een maatschappelijke ontwikkeling door een expert in een uitzending van Buitenhof, of om het lidmaatschap van een gespecialiseerd adviesorgaan. Wat dat betreft zou het KNAWadvies maatschappelijke relevantie ruimer kunnen interpreteren.

Bij lezing van het commentaar van de NSV bekruipt mij het omgekeerde gevoel: dat maatschappelijke relevantie van een onderzoeksafdeling onbegrensd is en daarmee ongefocust. Waarom niet het goede uit het voorstel van de KNAW behouden? Namelijk dat er een verband is tussen de maatschappelijke relevantie en het academische onderzoek van de afdeling. Dat de maatschappelijke verantwoordelijkheid vooral die verbanden van de Nederlandse samenleving betreft waar de afdeling verschil kan maken. Of het nu gaat om recent onderzoek, of om kennis en expertise die in de loop van de tijd is opgebouwd. Beperking als kwaliteitscriterium.

Misschien dat ik te somber ben en dat de NSV wel grenzen ziet aan de verantwoordelijkheid van de individuele academische socioloog en de afzonderlijke afdeling. Maar het advies is erg algemeen en vraagt bovendien om ruimte. Ik realiseer me dat ik ben beïnvloed door gesprekken met academici die vaak blijk geven van zo'n groot verantwoordelijkheidsgevoel en graagte dat het lijkt of ze, overdreven gesteld, in hun eentje verantwoordelijk zijn voor de hele relevantie van hun vakgebied. Ik huiver bij het lezen van 'publieke rol', omdat ik dat, mogelijk ten onrechte, interpreteer als de ambitie om ongericht te zenden naar iedereen in Nederland. Nogmaals, ik ben uitermate gevoelig op dit punt. Natuurlijk bouwt iedere socioloog voort op een groot sociaalwetenschappelijk kennisbestand en 
vanzelfsprekend delen sociologen de verantwoordelijkheid om voor de grote samenleving relevant te zijn. Maar de maatschappelijke verantwoordelijkheid van de onderwijssocioloog verschilt van die van de stadssocioloog. Ze richten zich op verschillende praktijken, waarbij andere schakels, publieken en communicatievormen horen. In veel gevallen is de samenleving het best gediend bij activiteiten die niet gericht zijn op de samenleving in haar geheel, maar op een specifieke groep, organisatie of praktijk. Daarom schrijf ik bijvoorbeeld dit artikel. Ik denk dat mijn bijdrage aan het onderhavige debat, dat uiteindelijk relevant is voor de hele Nederlandse samenleving, goed tot zijn recht komt in dit blad. Het mooie is dat het ook inhoudelijk interessant is voor mij. Ik hoop op reacties die mij weer verder helpen bij het scherpen van mijn analyse van wat er toch aan de hand is met dat problematische begrip 'valorisatie' en wat het toch zo moeilijk maakt om onderzoek evenwichtig te beoordelen.

Bij het ontwikkelen van een visie op maatschappelijke (en wetenschappelijke) relevantie horen keuzes en focus om, gericht, een verschil te kunnen maken. Het helpt ook om de toch al volle agenda's enigszins te reguleren. Ik pleit dus voor het maken en bespreken van keuzes.

Het tweede bezwaar betreft de lijdende vorm en de lijdzame toon die de NSV in een groot deel van het advies hanteert. Ik vroeg me bij lezing voortdurend af wie of wat de oorzaak is van de huidige situatie. De maatstaven voor onderzoeksbeoordeling moeten grondig worden herzien en het tij moet gekeerd, maar het is niet duidelijk door wie. Ook is het niet duidelijk wie er verantwoordelijk is voor het toepassen van de in zwang zijnde wetenschapsmetingen. Het zou kunnen dat de bestuurders in alle gevallen de boosdoener zijn, maar dat lijkt me een zwaktebod. En een brochure van 36 pagina's lijkt me niet de juiste wijze om deze drukbezette doelgroep te bereiken.

De NSV schrijft dat er een radicale omzwaai nodig is van universitaire bestuurders. Naar mijn stellige overtuiging zijn de enigen die een omzwaai kunnen realiseren, de sociologen zelf. Het advies kan een rol spelen, maar daarmee is het tij nog niet gekeerd. Want het gaat er nu om dat sociologen de verantwoordelijkheid nemen en de discussie over de maatschappelijke bijdragen van sociologisch onderzoek en de kwaliteitsbeoordeling gaan of blijven voeren, zowel met hun bestuurders als met collega's. Ik kan me ook niet voorstellen dat sociologen erbij gebaat zouden zijn als universitaire bestuurders bepalen wat voor soort bijdrage ze precies verwachten van de sociologie. Het lijkt mij verstandig dat de sociologen daar zelf de leiding in nemen. Iedereen heeft daarin zijn of haar eigen verantwoordelijkheid. De decaan en rector die invulling geven aan de maatschappelijke taak van de universiteit en aan de profileringsafspraken die zij hebben gemaakt met het ministerie, door met afdelingen een inhoudelijk gesprek te voeren over de betekenis hiervan. De onderzoeksdirecteur die het instituut beschouwt in termen van een onderzoeksportfolio: variatie van inhoudelijke expertise en variatie van meer of minder maatschappelijke oriëntatie. Die bovendien in formele HRM-gesprekken (sollicitaties, jaargesprekken) ook maatschappelijke aspecten van onderzoek bespreekt en waardeert, én dit met de decaan bespreekt. De groepsleider die de keuze maakt om in de dagelijkse begeleiding ook maatschappelijke aspecten van 
het onderzoek te bespreken, de verantwoordelijkheid hierover deelt en het als taak ziet de promovendus ook daarin te begeleiden. En zich vervolgens bij zijn of haar leidinggevende hard maakt voor deze keuzes. De promovendus die met begeleiders spreekt over de relevantie van het promotieonderzoek, en dan niet alleen over de belofte van relevantie, maar ook over manieren om die relevantie te realiseren in de praktijk.

Voor een deel heeft de NSV het tij mee. De VSNU heeft onlangs afspraken gemaakt met het ministerie van OCW over valorisatie-indicatoren (VSNU 2013). In lijn met de overige Nederlandse adviezen is het model dat de VSNU hanteert geschikt voor alle mogelijke disciplines. Het model is deels leeg - in te vullen naar eigen behoefte en passend bij de eigen instelling of discipline. Dit betekent niet alleen dat de VSNU in de Nederlandse traditie staat, maar ook dat de VSNU dus niet heeft vastgesteld wat de juiste indicatoren zijn. Er zijn in Nederland geen vaste afspraken over indicatoren voor valorisatie, anders dan dat betrokkenen zelf passende indicatoren formuleren. Dit legt een grote verantwoordelijkheid bij die betrokkenen, en nodigt ze tevens uit om te formuleren wat valorisatie betekent. Of in de woorden van de NSV: op welke wijze een afdeling sociologie de samenleving dient.

Of het nu gaat om de beoordeling van valorisatie, om de beoordeling van academisch onderzoek in het algemeen, of om de bepaling van de maatschappelijke bijdrage van een afdeling, Nederland kent een lange traditie van grote autonomie en verantwoordelijkheid van onderzoeksafdelingen. De NSV levert een belangrijke bijdrage aan al deze onderwerpen door het publiceren van dit advies. Maar daarmee begint het pas. Uit het advies wordt duidelijk dat de sociologen stevige gesprekken moeten voeren. Deze gesprekken moeten gaan over de koers en oriëntatie van de afzonderlijke afdelingen en in het bijzonder over de relatie met de maatschappij, die volgens de NSV nogal is verwaarloosd. En vervolgens over de passende wijze om de bijdragen te beoordelen. Ik pleit er voor die verantwoordelijkheid te nemen en benutten.

Nog een laatste opmerking. De NSV betwijfelt of de internationaliseringstrend het maatschappelijk draagvlak ten goede is gekomen. Ik begrijp de twijfel en had graag willen melden dat dat zo is. In twee verschillende onderzoeken vinden wij echter aanwijzingen voor het omgekeerde (Tiemeijer \& De Jonge 2013; Ketting 2013). Het vertrouwen in wetenschap is uitermate hoog. Burgers lijken verder een tamelijk naïef beeld te hebben van wetenschap en wetenschappelijk onderzoek als objectieve en ware bron van kennis. Het vertrouwen neemt snel af als burgers de indruk hebben dat er onderzoek wordt gedaan 'waarvan we de uitkomst allang wisten' (Jan Blokker leeft voort), als onderzoek wordt gefinancierd door derden (overheid, bedrijven, ngo's) of als ze de indruk hebben dat onderzoek 'nuttig' moet zijn.

Betekent dit een betoog voor opsluiting in de eigen onderzoeksgemeenschap en verdere academic drift? Nee, integendeel. Maar om teleurstellingen te voorkomen: reken niet op massale bijval als het tij is gekeerd. Vul de publieke functie niet in door disseminatie richting het grote publiek. Maak geen keuzes voor de bühne, 
maar maak noodzakelijke keuzes om relevante bijdragen te leveren en neem verantwoordelijkheid om de academic drift tegen te gaan.

\section{Geraadpleegde literatuur}

Drooge, L. van, R. Vandeberg et al. (2011) Waardevol: Indicatoren voor valorisatie. Den Haag: Rathenau Instituut.

ERiC (2010) Handreiking evaluatie van maatschappelijke relevantie van wetenschappelijk onderzoek. Den Haag: ERiC-publicatie 1001.

Harwood, J. (2010) Understanding Academic Drift: On the Institutional Dynamics of Higher Technical and Professional Education. Minerva, 48: 413-427.

Ketting, E. (2013) Geachte wetenschap - Stageverslag van een onderzoek naar beelden over wetenschap in lezersbrieven. Den Haag: Rathenau Instituut.

KNAW (2011) Kwaliteitsindicatoren voor onderzoek in de geesteswetenschappen. Amsterdam: KNAW.

KNAW (2012) Kwaliteit en relevantie in de geesteswetenschappen: Naar een adequaat systeem voor de beoordeling van wetenschappelijk onderzoek. Amsterdam: KNAW.

KNAW (2013) Naar een raamwerk voor de kwaliteitsbeoordeling van sociaalwetenschappelijk onderzoek. Amsterdam: KNAW.

Tiemeijer, W. en J. de Jonge (2013) Hoeveel vertrouwen hebben Nederlanders in wetenschap? Den Haag: Rathenau Instituut.

VSNU (2013) Een Raamwerk Valorisatie-indicatoren. Den Haag: VSNU. 